\title{
Monopsony with nominal rigidities: an inverted Phillips Curve
}

\author{
Charles Dennery ${ }^{1}$ \\ Chair of International Finance, Ecole Polytechnique Federale de Lausanne
}

\begin{abstract}
With nominal wage rigidities, it is crucial to distinguish whether wages are set by workers or firms - whether we have monopoly or monopsony power. This paper provides a model of monopsony power in the labour market and a monopsonistic Phillips Curve. If wages are set by firms who face nominal rigidities, and there is inflation, firms cannot adjust their wages fully. The real wage falls, and labour supply hence output decreases. This provides a Phillips Curve where the output gap is negatively correlated with wage inflation. In such a world monetary policy affects the intertemporal labour supply, while the Phillips Curve is a labour demand curve. Interest rate cuts reduce the labour supply instead of boosting demand: they are contractionary.
\end{abstract}

JEL codes: E24, E31, E52, J42

Keywords : monopsony, nominal rigidities, Phillips curve

1

${ }^{1}$ Email: charles.dennery@epfl.ch. I am grateful to Gianluca Benigno and Ricardo Reis for their guidance in this project. I also want to thank Alan Manning, Wouter den Haan, Luisa Lambertini, as well as Laura Castillo-Martinez, Chao He, Christian Proebsting, Marc-Antoine Ramelet and one anonymous referee for useful discussions and comments. All errors are mine.

${ }^{2}$ Robinson (1933) originally defined monopsony as a market situation in which there is only one buyer, as opposed to monopoly with only one seller. More generally, it also encompasses any situation of imperfect competition where buyers dominate their input market, and face an elastic supply curve so that they can choose the price (or wage) that they offer. Firms with monopsony power can set lower wages than in a competitive market. 
4 (documented for example in CEA (2016) or IMF (2017)), monopolistic unions 5 are no longer a good description of the labour market. The increase in self- employment, flexible and part-time work - the so called gig economy - has made 7 work more divisible and insecure (Haldane 2017). However, the consequence of 8 these trends in labor market power for monetary policy is unclear. Is monopsony 9 simply leading to lower wages? Or is there a more fundamental change? New 10 Keynesian models assume that suppliers have market power and set their rates: 11 the producer sets her own price, and/or the worker/union sets her own wage.

12 What happens when wages are set by employers instead of employees, and Monopsony and the Phillips Curve

The New Keynesian model with nominal wage rigidities usually assumes that wages are set by workers or unions having monopoly power. Individual workers or unions face a labor demand curve that is not perfectly elastic. They commit to a wage and are willing to work any amount at this wage. Hence the economy is (labour) demand-constrained. Here, I look instead at the effect of monopsonistic employers setting wages for their employees. Individual employers face an elastic labour supply curve : they have monopsony power. Since they commit to provide employment to anyone willing to work at the posted wage, the economy is now (labour) supply-constrained. ${ }^{3}$

In the NK wage monopoly model, firms' demand for labour is the result of an intertemporal Euler equation: if wages are higher today than tomorrow, or with high real rates, firms demand less labour today. Hence high interest rates reduce labour demand, while labour supply is fixed by nominal rigidities and doesn't react to the interest rate. On the other hand, if nominal rigidities apply to the demand side, labour demand no longer reacts to the interest rate,

\footnotetext{
${ }^{3}$ With monopsony there is no notion of voluntary unemployment; instead there is voluntary job rationing: firms' labour demand is inefficiently low given the low real wage.
} 
but the supply of labour does, with an Euler equation. If wages are higher today than tomorrow, or with high real rates, workers will work more today, and enjoy more leisure tomorrow: high interest rates are expansionary. ${ }^{4}$ Since shocks to the natural or nominal rate of interest now affect the intertemporal supply equation, and not the intertemporal demand equation as before, they now qualify as supply shocks - instead of demand shocks.

\section{Related literature}

Monopsony (or oligopsony) has been studied both theoretically and empirically in the labour literature, as well as in other markets (see, among others, Manning 2003, Murray 1995 or more recently Morlacco 2019). Theoretical models of monopsony have usually relied on the Salop (1979) or Hotelling (1929) models of geographical differentiation, or on search frictions as in Burdett and Mortensen (1998). Recent papers of oligopsony in the labour market such as Berger et al. (2019) have relied instead on a model with a constant elasticity of substitution. Based on Horvath (2000), it is the mirror analog of CES monopolistic competition: workers have a taste for diversity and work in several firms $/$ sectors $^{5}$ - as opposed to monopolistic competition as in Erceg et al. (2000) where firms have a taste for diversity and work with different worker types. A CES model is particularly tractable and suitable to study the interaction of monopsony and inflation, which is the key novel contribution of this paper.

This paper is also related to to the recent literature looking at the growing role of very large and powerful firms. Eeckhout and de Loecker (2018), or Gutierrez and Philippon (2017) have documented an increase in monopoly power, where firms charge higher prices, and output is sub-optimally low. Policymakers such as CEA (2016) and IMF (2017) have highlighted the shift of bargaining

\footnotetext{
${ }^{4}$ The usual NK model with price rigidities and flexible wages can also feature this intertemporal equation. It is however irrelevant, because nominal rigidities only apply to goods not labour, and the relevant Euler equation relates to the demand for goods.

${ }^{5}$ Horvath (2000) assumes that agents share their time across sectors while for me it is across firms. While most people work with only one employer in real life, this simplification can be rationalised with a discrete choice model, along the lines of Anderson et al (1987).
} 
57 power from employees to employers, new features of the labour markets, and the

58 resulting effect on weak wage growth but without looking at monopsony power

59 specifically. Recent papers have looked at the link between monopsony power

60 and weak wage growth. Azar et al. (2017) find a strong negative relationship

61 between monopsony power and wages in the US. Looking at US manufacturing,

62 Benmelech et al. (2018) document the same effect, though on a much smaller

63 scale. Abel et al. (2018) find similar results to Benmelech et al. in the UK, for

64 a larger firm sample.

65 Last, this paper is related to the debate on the shape of the Phillips Curve

66 (Ball and Mazumder 2011, Blanchard 2016). It is also indirectly related to the

67 reversal rate literature (Brunnermeier and Koby, 2018), where interest rates

68 below a certain level become contractionary due to financial frictions, although

69 the channel of contractionary low interest rates is different here.

70 The rest of the paper is organised as follows. Section 2 builds a model of 71 monopsony, derives a monopsonistic Phillips Curve, interprets monetary policy

$\mathbf{7 2}$ in this setup and discusses the results. Section 3 concludes.

\section{The Phillips curve with monopsony}

In this section I build a model of monopsony power in the labour market, which allows me to write a monopsonistic Phillips Curve.

\subsection{Flexible steady state}

Let me first set up the model without nominal rigidities.

\section{Households}

As in Horvath (2000), a worker allocates its time across different employers: there is a continuum of firms, indexed by $i \in[0,1]$. By working $L_{i}$ with each employer $i$ (at a wage $W_{i}$ ), the total wage received is $\int_{0}^{1} W_{i} L_{i} d i$. Disutility of 
82

${ }_{83} \quad$ labour $L_{t}(i)$ supplied to each firm $i:^{6}$

$$
L_{t}=\left[\int_{0}^{1} L_{t}(i)^{1+1 / \eta} d i\right]^{\frac{1}{1+1 / \eta}}
$$

${ }_{84} \eta=\left.\frac{\partial \ln L_{i}}{\partial \ln W_{i}}\right|_{L, C}$ is the wage elasticity of labour supply.

${ }_{85}$ The consumption good $C_{t}$ is assumed to be homogeneous at a price $P_{t}$. The s6 representative households maximizes a separable utility function, subject to a ${ }_{87}$ budget constraint:

$$
\begin{array}{r}
\max _{0} \sum_{t=0}^{+\infty} \beta^{t}\left[U\left(C_{t}\right)-V\left(L_{t}\right)\right] \\
\text { st. } \quad P_{t} C_{t}+Q_{t} B_{t}=B_{t-1}+\int_{0}^{1} W_{t}(i) L_{t}(i) d i+\int_{0}^{1} D_{t}(i) d i
\end{array}
$$

s8 $\quad$ From every firm $i$, the household receives a dividend $D_{t}(i)$, and a wage 89 compensation $W_{t}(i) L_{t}(i)$ for supplying $L_{t}(i)$ to firm $i$. New bonds $B_{t}$ can be bought or sold at price $Q_{t}$, the stochastic discount factor of the household.

The Euler equation pins down the stochastic discount factor

$$
Q_{t}=\mathrm{E}_{t} \beta \frac{P_{t}}{P_{t+1}} \frac{U^{\prime}\left(C_{t+1}\right)}{U^{\prime}\left(C_{t}\right)}
$$

92 The first order condition for each $L_{t}(i)$ brings

$$
\frac{u^{\prime}\left(C_{t}\right)}{P_{t}} W_{t}(i)=\left(\frac{L_{t}(i)}{L_{t}}\right)^{1 / \eta} V^{\prime}\left(L_{t}\right)
$$

93 There is a substitution across jobs, and between leisure and consumption:

\footnotetext{
${ }^{6}$ See Berger et al. (2019) for a discrete choice probabilistic microfoundation of this monopsony assumption, along the lines of Anderson et al (1987): workers have idiosyncratic preferences over different types of jobs and work for only one employer. As relative wages change, some workers fully substitute to a new occupation, creating imperfect aggregate substitutability. If preferences follow a Gumbel distribution, this results in CES.
} 
${ }_{94}$ Property 1 . Write $W_{t}$ the wage aggregate as

$$
W_{t}=\left[\int_{0}^{1} W_{t}(i)^{1+\eta} d i\right]^{\frac{1}{1+\eta}}
$$

95 (1) As the worker takes prices and wages as given, the aggregate real wage is

96 equal to the marginal rate of substitution (MRS) of labour and consumption:

$$
\frac{W_{t}}{P_{t}}=\frac{V^{\prime}\left(L_{t}\right)}{U^{\prime}\left(C_{t}\right)}=M R S_{t}
$$

(2) Firm i's relative labour supply is a function of its relative wage:

$$
\frac{L_{t}(i)}{L_{t}}=\left(\frac{W_{t}(i)}{W_{t}}\right)^{\eta}
$$

98

(3) Combining the $M R S=\frac{W}{P}$ condition with the Euler equation of consumption, one can write an intertemporal labour supply equation:

$$
Q_{t} \frac{V^{\prime}\left(L_{t}\right)}{W_{t}}=\beta \mathrm{E}_{t} \frac{V^{\prime}\left(L_{t+1}\right)}{W_{t+1}}
$$

In logs, with $r^{n}=-\ln \beta$, this writes $v^{\prime}\left(l_{t}\right)=\left(i_{t}-E_{t} \pi_{t+1}^{w}-r^{n}\right)+E_{t} v^{\prime}\left(l_{t+1}\right)$

At the optimum, the worker is indifferent between earning $1 \$$ tomorrow, or earning $Q_{t}$ today to buy a bond yielding $1 \$$ tomorrow. This intertemporal labour supply equation doesn't exist when monopolistic workers set sticky wages since they do not choose their labour supply. As explained in footnote 4 above, this equation holds but it is irrelevant when wages are flexible.

Firms

Representative firm $i$ takes prices as given, and has a production function $Y_{t}(i)=F\left(L_{t}(i)\right)$. It maximizes its profits subject to the labour supply curve:

$$
\max _{L_{t}(i), W_{t}(i)} P \cdot F\left(L_{t}(i)\right)-W_{t}(i) \cdot L_{t}(i) \quad \text { st. } \quad\left(\frac{L_{t}(i)}{L_{t}}\right)=\left(\frac{W_{t}(i)}{W_{t}}\right)^{\eta}
$$


The optimal wage is below the marginal product of labour (MPL):

$$
W_{t}(i)=\frac{P_{t} \cdot F^{\prime}\left(L_{t}(i)\right)}{1+1 / \eta} \quad \frac{W_{t}}{P_{t}}=\frac{M P L_{t}}{1+1 / \eta}
$$

\section{Property 2 (Calvo monopsonistic Phillips Curve).}

$$
\pi_{t}^{w}=\frac{(1-\beta \theta)(1-\theta)}{\theta}\left(\frac{-1}{1+\alpha \eta}\right)\left(m r s_{t}-m p l_{t}\right)+\beta \mathrm{E}_{t}\left[\pi_{t+1}^{w}\right]
$$

${ }_{118} \alpha=\frac{-L F^{\prime \prime}(L)}{F^{\prime}(L)}$ is the elasticity of the production function and $\frac{(1-\beta \theta)(1-\theta)}{\theta}$ comes

from the Calvo modeling. $\mathrm{mrs}_{t}$ and $\mathrm{mpl}_{t}$ are the log deviations of the MRS and MPL at $t$, hence $\left(m r s_{t}-m p l_{t}\right)$ is a measure of real economic activity. Monopsony only plays a role through $\eta$ and the negative sign.

\footnotetext{
${ }^{7}$ The log approximation of the optimal Calvo wage (dropping the markup) is $w_{t}^{*}=(1-\beta \theta) \sum_{k=0}^{+\infty}(\beta \theta)^{k}\left[p_{t}+m p l_{t+k \mid t}\right]$. If $m p l=-\alpha l, m p l_{t+k \mid t}=m p l_{t+k}+\alpha \eta\left(w_{t+k}-w_{t}^{*}\right)$. Using the fact that $m r s=w-p$, and standard algebra, the Phillips Curve can be derived.
} 


\footnotetext{
${ }^{8}$ Most models with sticky wages also feature sticky prices. However I assume flexible prices to make the two models most comparable. When firms with goods monopoly power and labour monopsony power face nominal rigidities in both markets, output depends on a difference of the price and wage inflation, instead of an average as in EHL (see Dennery, 2020).

${ }^{9}$ The normal NK model with sticky wages and flexible prices typically displays employers with a taste for diversity among worker types, with an elasticity of substitution $\epsilon$. With $\phi$ the disutility curvature, the Calvo wage monopoly Phillips Curve can be written

$$
\pi_{t}=\frac{(1-\beta \theta)(1-\theta)}{\theta}\left(\frac{1}{1+\phi \epsilon}\right)\left(m r s_{t}-m p l_{t}\right)+\beta \mathrm{E}\left[\pi_{t+1}\right]
$$

${ }^{10}$ The typical price NK model features 3 equations: the price PC, the Euler equation of consumption, and a Taylor rule as a function of price inflation. In the wage monopoly model, we have 4 equations: the wage PC, a wage inflation Taylor rule, the Euler equation of consumption, and the condition $W / P=M P L$. Eq (8) combines these last two for simplicity.
} 
combined with the upward-sloping labour supply PC with wage inflation and labour $\pi_{t}^{w}=\beta \mathrm{E}_{t} \pi_{t+1}^{w}+\lambda\left(m r s_{t}-m p l_{t}\right)$

On the other hand, in the monopsony wage model, the Phillips Curve is a demand curve in terms of labour and wage inflation. The corresponding intertemporal labour supply curve is eq. (5), which in logs becomes ${ }^{11}$

$$
v^{\prime}\left(l_{t}\right)=\left(i_{t}-\mathrm{E}_{t} \pi_{t+1}^{w}-r_{t}^{n}\right)+\mathrm{E}_{t} v^{\prime}\left(l_{t+1}\right)
$$

With a Taylor rule $i_{t}=\phi \pi_{t}^{w},{ }^{12}$ this provides a positive supply relationship between wage inflation and labour - for given expectations of future variables. It is then combined with the downward-sloping monopsony $\mathrm{PC}$, which is the firms' labour demand equation: $\pi_{t}^{w}=\beta \mathrm{E}_{t} \pi_{t+1}^{w}-\lambda\left(m r s_{t}-m p l_{t}\right)$.

In what follows, I assume the following Taylor rule: $i=\phi_{\pi}^{w} \pi^{w}$. The difference between the wage monopoly and monopsony models is displayed in figure 1, and does not depend qualitatively on the specific calibration of the two models. Under monopoly the Phillips Curve (PC) is a supply curve combined with an intertemporal demand curve (D), while under monopsony it is a demand curve combined with an intertemporal supply curve (S). ${ }^{13}$

\section{Interest rate shocks}

Under monopoly, a drop in the policy rate (or an increase in the natural interest rate) raises demand. Output increases above its potential, the positive output gap raises wage inflation. Conversely, under monopsony, impatience lowers the labour supply today relative to tomorrow. With a negative output gap, inflation increases and raises the nominal and real rates.

\footnotetext{
${ }^{11}$ Under monopsony we have 4 equations: the wage $\mathrm{PC}$, a wage inflation Taylor rule, the Euler equation of consumption, and $W / P=M R S$. Eq (9) combines these last two.

${ }^{12}$ Under monopsony, with a Taylor rule $i=\phi_{y} y+\phi_{\pi}^{w} \pi^{w}$, the analog of the Bullard and Mitra (2002) condition becomes $\phi_{\pi}^{w}-\frac{1-\beta}{\kappa} \phi_{y}>1$. Hence the rule is unchanged if $\phi_{y}=0$.

${ }^{13}$ Denote $\sigma=-C U^{\prime \prime}(C) / U^{\prime}(C), \alpha=-L F^{\prime \prime}(L) / F^{\prime}(L)$ and $\phi=L V^{\prime \prime}(L) / V^{\prime}(L)$.

In the monopoly case, the monopoly $\mathrm{PC}$ and labour demand equation write, respectively: $\pi_{t}^{w}=\beta \mathrm{E}_{t} \pi_{t+1}^{w}+\lambda(\sigma(1-\alpha)+\phi+\alpha) l_{t}$ and $(\sigma(1-\alpha)+\alpha)\left(l_{t}-\mathrm{E}_{t} l_{t+1}\right)=-\left(i_{t}-\mathrm{E}_{t} \pi_{t+1}^{w}-r_{t}^{n}\right)$. In the monopsony case, the monopsony $\mathrm{PC}$ and labour supply equation write, respectively: $\pi_{t}^{w}=\beta \mathrm{E}_{t} \pi_{t+1}^{w}-\tilde{\lambda}(\sigma(1-\alpha)+\phi+\alpha) l_{t}$ and $\phi\left(l_{t}-\mathrm{E}_{t} l_{t+1}\right)=\left(i_{t}-\mathrm{E}_{t} \pi_{t+1}^{w}-r_{t}^{n}\right)$.
} 

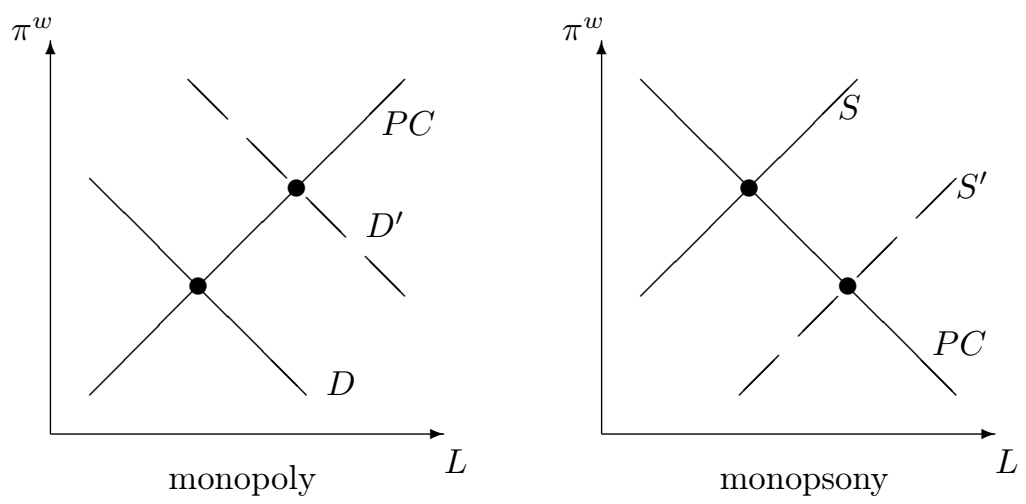

Figure 1: The monopoly vs. monopsony models. Under monopoly the PC is a supply curve, while it is a demand curve under monopsony. The dashed lines show the effect of a decrease in the policy rate $i$, or an increase in $r^{n}$.
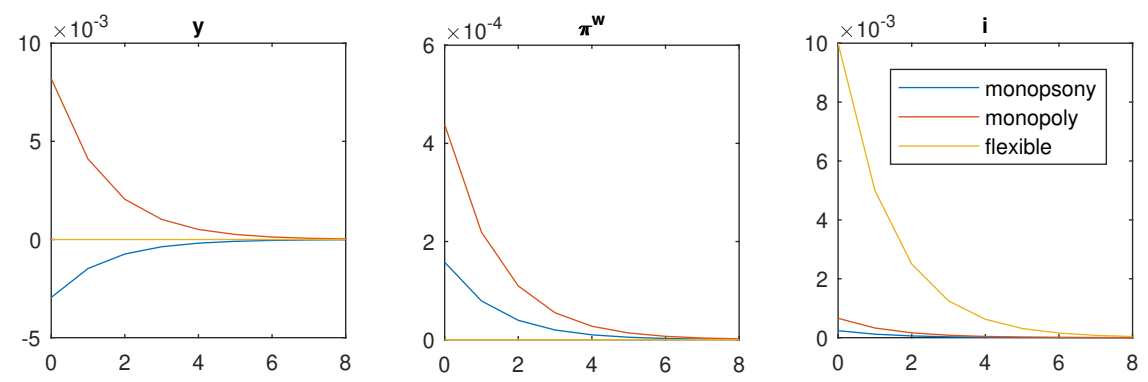

Figure 2: Response of $\left(y, \pi^{w}, i\right)$ to an impatience shock

Figure 2 shows that qualitatively, inflation and interest rates increase in both models (though the magnitude depends on calibration). As the real interest rate doesn't increase enough to match the increased impatience, output increases under monopoly but falls under monopsony. Crucially with monopsony, impatience shocks are no longer positive demand shocks, but negative supply shocks, as they apply to the intertemporal supply curve now.

\section{Conclusion}

This paper first introduced a model of monopsonistic competition with a constant elasticity of substitution (CES) between jobs similar to Horvath (2000). While the monopolistic competition model features imperfect substitution of employers between workers or worker types - a love of variety - monopsonistic 
competition features imperfect substitutability of workers across different employers or job types. Workers prefer to work for different employers as it brings a lower disutility than working for one sole employer.

Having introduced this model of monopsony, it is easy to build a New Keynesian model with wages set by monopsonistic employers. The difference with the classical monopoly Phillips Curve is that the output-inflation correlation becomes negative. Since interest rate shocks affect the intertemporal labour supply curve instead of the consumption demand curve, these interest shocks have the opposite effect of the normal monopoly case. An interest rate drop reduces the labour supply and is contractionary.

Looking at heterogeneity is an obvious avenue for future research. Employers have monopsony power in some sectors while others still show employee monopoly power. Studying mega firms with both monopoly power over their consumers and monopsony power over their employees is another promising path that I explore in Dennery (2020): output then depends on a difference between price and wage inflation. Last, shifting the bargaining power - and wage rigidities - from workers to firms would also add realism: the slope of the Phillips Curve would now depend on both sides' relative bargaining power.

\section{References}

[1] Abel, W., Tenreyro, S., and Thwaites, G. (2018). Monopsony in the UK. CEPR Discussion Paper 13265.

[2] Anderson, S., De Palma, A., and Thisse, J.-F. (1987). The CES is a discrete choice model? Economics Letters, 24(2):139-140.

[3] Azar, J., Marinescu, I., and Steinbaum, M. (2017). Labor market concentration. NBER WP 24147.

[4] Ball, L. and Mazumder, S. (2011). Inflation Dynamics and the Great Recession. NBER WP 17044.

[5] Benmelech, E., Bergman, N., and Kim, H. (2018). Strong employers and weak employees: How does employer concentration affect wages. NBER WP 24307. 
[6] Berger, D., Herkenhoff, K., and Mongey, S. (2019). Labor Market Power. NBER WP 25719.

[7] Blanchard, O. (2016). The Phillips Curve: Back to the 60s? American Economic Review, 106(5):31-34.

[8] Bullard, J. and Mitra, K. (2002). Learning about monetary policy rules. Journal of Monetary Economics, 49(6):1105 - 1129.

[9] Burdett, K. and Mortensen, D. (1998). Wage Differentials, Employer Size, and Unemployment. International Economic Review, 39(2):257-273.

[10] CEA (2016). Labor market monopsony: trends, consequences, and policy responses. Council of Economic Advisers Issue Brief (Oct. 2016).

[11] De Loecker, J. and Eeckhout, J. (2018). Global Market Power. NBER WP 24768.

[12] Dennery, C. (2020). Monopsony, Megafirms and Monetary Policy. mimeo.

[13] Erceg, C., Henderson, D., and Levin, A. (2000). Optimal monetary policy with staggered wage and price contracts. Journal of Monetary Economics, $46(2): 281-313$.

[14] Gutiérrez, G. and Philippon, T. (2017). Declining Competition and Investment in the US. NBER WP 23583.

[15] Haldane, A. (2017). Work, Wages and Monetary Policy. speech given at Bradford.

[16] Horvath, M. (2000). Sectoral shocks and aggregate fluctuations. Journal of Monetary Economics, 45(1):69-106.

[17] Hotelling, H. (1929). Stability in Competition. The Economic Journal, 39(153):41-57.

[18] IMF (2017). Recent Wage Dynamics in Advanced Economics. In World Economic Outlook (Oct. 2017). International Monetary Fund.

[19] Manning, A. (2003). Monopsony in motion: Imperfect competition in labor markets. Princeton University Press.

[20] Morlacco, M. (2019). Market Power in Input Markets: Theory and Evidence from French Manufacturing. mimeo.

[21] Murray, B. C. (1995). Measuring Oligopsony Power with Shadow Prices. The Review of Economics and Statistics, 77(3):486-498.

[22] Robinson, J. (1933). The Economics of Imperfect Competition. London Macmillan.

[23] Salop, S. (1979). Monopolistic Competition with Outside Goods. The Bell Journal of Economics, 10(1):141-156. 